\title{
TRADITIONAL PRODUCTS - BASE FOR THE SUSTAINABLE DEVELOPMENT OF SERBIAN ANIMAL ORIGIN PRODUCTS*
}

\author{
Jasna Lj. Stevanović ${ }^{1}$, Đorđe G. Okanović ${ }^{2}$, Slavica V. Stevanetić ${ }^{\text {, }}$ Milorad D. Mirilović $^{3}$, \\ Neđeljko R. Karabasil ${ }^{3}$, Snježana R. Pupavac ${ }^{4}$ \\ ${ }^{1}$ Chamber of Commerce and Industry of Serbia, Resavska 15, \\ 11000 Belgrade, Serbia \\ ${ }^{2}$ University of Belgrade, Faculty of Veterinary Medicine, Bul. oslobođenja 18, \\ 11000 Belgrade, Serbia \\ ${ }^{3}$ University of Novi Sad, Institute of Food Technology, Bulevar cara Lazara 1, \\ 21000 Novi Sad, Serbia \\ ${ }^{4}$ EKO LAB doo Padinska Skela, Industrijsko naselje bb., Serbia
}

Corresponding author: Đorđe Okanović

Phone: +381214853707

E-mail address: djordje.okanovic@fins.uns.ac.rs

\begin{abstract}
Research results on the diversity of traditional products of animal origin from certain areas of the Republic of Serbia, provides an opportunity to become part of the sustainable quality development, which would be based on their promotion and protection of local resources.

Traditional products of animal origin are different and inseparable from the local identity, typical for nation and its food culture. Through confidence-building, and protection from oblivion, the value of domestic products, had preserved trough centuries-old tradition. Nowadays, each domestic product has its own recognisable taste, representing climate of the Republic of Serbia, from which it comes. Universally accepted model of rural institutional structure does not exist. Instead it accommodates and develops in accordance to needs, possibilities and area specific characteristics. By the efficient protection rural models becomes an investment incentives and contribute to general economic and industrial prosperity of the society.
\end{abstract}

Keywords: traditional products, animal origin, Serbia, region, efficient protection

\section{INTRODUCTION}

The favourable geographical position of the Republic of Serbia is supported by the fact that we belong to the group of the European countries with a large area of arable land, but with the lower percentage of its utilization. The specificity of the Republic of Serbia is also reflected in the presence of plentiful small farms, so we deal with predominantly rural population, which is engaged in agriculture. One of the indicators of the general situation in the country, and of the agricultural development as well, stems from the data on the balance of trade in agricultural products. Although there is an increase in the favourable balance, the Republic of Serbia still does not reach its maximum due to the noted structural instability. Economic progress in the Republic of Serbia should be interconnected with the social development of the country (UNESCO, n.d.). Inherited values of traditional products

*This work was reported at the III International Congress "Food Technology, Quality and Safety" held in Novi Sad, Serbia, October 25-27, 2016, organized by the Institute of Food Technology, University of Novi Sad, Serbia. 
should rightfully be considered as equally important as the rules imposed by the development of the international food standards. The purpose of geographical indications and the names of the protection of origin, traditionally produced or a certification of organic production, have the goal of establishing the basis for increasing profits (Ministarstvo poljoprivrede, šumarstva i vodoprivrede RS, 2009). Preserving the characteristic quality of a product of animal origin encourages both the advancement and the sustainability of high-level biological diversity which can be found in Serbia. One of the certain and useful tools for the regional development is finding an opportunity for additional interest of domestic producers, taking into account predominantly rural character of the Republic of Serbia (Stevanović et al., 2016).

France and Italy prove that professionally developed system for the protection of geographical origin brings greater profit and greater success, but similar examples can also be found both in other member states of the European Union and outside the EU.

\section{BASIS FOR RESEARCH}

Free movement of agricultural products is an objective of a single market organisation. This, primarily, implies harmonisation of different qualities of products (Pravilnik o kvalitetu usitnjenog mesa, poluproizvoda od mesa i proizvoda od mesa, 2012), by mandatory regulations on packaging and product labelling (Pravilnik o deklarisanju, označavanju i reklamiranju hrane, 2013). The aforementioned rules on packaging and labelling imply all the necessary analyses and supervision in order to ensure the product safety.

Horizontal rules on free movement of goods include protection of designation of origin and protection of geographical indications. Horizontal rules on protection of products also provide protection of specific regional identity (Zakon o oznakama geografskog porekla, 2010).

A safe way towards the advancement and sustainability of agricultural production is organic farming. The implementation of prescribed methods and procedures maximizes soil productivity, but at the same time minimizes harmful effects on soil, water, air and health, both producer's and consumer's. Unlike conventional production, organic production is based on biological balance of the system soil - plant animal - human. Although it accounts for only $1 \%$ of the total world's food market, organic products are becoming increasingly demanded goods and their share in world trade flows is becoming more important.

The steady growth in demand for organic products in the world indicates that this method of production can be quite profitable if natural resources, manufacturing experience and expertise are used and implemented properly. Organic farming is considered to be environmentally and economically sustainable and socially responsible. Organic farming preserves natural resources from complete destruction or eradication (Zakon o organskoj poljoprivredi, 2000).

\section{UNIQUENESS OF TRADITIONAL PRODUCTS OF ANIMAL ORIGIN FROM SERBIA}

On the whole, rich flora (mushrooms, herbs, forest fruit, etc.) enabled the growth of fauna in the Republic of Serbia. Not only does Serbia have a favourable geographical position and natural resources, but it has its history, cultural heritage with deep roots and honourable past, which entails traditional ways of food production. Although Slavs are one of the oldest nations in this area, it is the Turkish cuisine that has had the most prominent influence on Serbian cuisine. Thus, most of current specialties in eastern and southern Serbia were inspired by that influence, while the Austro-Hungarian influence is present particularly in Vojvodina.

However, when talking about Serbia in its entirety, we should not ignore the culinary variety of different traditional and acquired influences.

Bearing in mind that the protection of geographical designation of origin protects the name of a region, a specific place or, 
in exceptional cases, the whole country, in order to describe the products or food originating from that area, it is clear that Serbia is famous for that. Hence, there are honey from Homolje mountains, linden honey from Fruška gora mountain, honey from the village of Kačer, grilled meat from the town of Leskovac, belmuž (a traditional shepherd dish made of cheese and cornflour) from the town of Svrljig, duvan čvarci (a specific type of pork rinds) from the town of Valjevo.

The water opulence in Serbia is special due to the diversity of the ecosystem and fishing is very common. The carp of the town of Ečka is a species protected with the designation of origin. The caviar of Kladovo is also well-known. In the upper course of the Mlava, near the source, there is a famous trout farm. We should emphasise that the Mlava flows through the District of Braničevo throughout its course, which can be an important characteristic of the trout grown here.

Over the past few years, the Republic of Serbia has increasingly been turning to organic farming. It is most prevalent in the Province of Vojvodina followed by the regions of southern and eastern Serbia. Organic livestock farming implies certification, which imposes specific demands for animal nutrition, animal housing, and animal care and farming as well. More information on the demands and rules of organic livestock farming is contained in the Rulebook on Methods of Organic Livestock Production (Pravilnik o metodama organske stočarske proizvodnje, 2002). One of the most important factors in successful organic livestock farming refers to the proper choice of animal species and breeds. Under the national regulation of the Republic of Serbia, domestic milk products with geographical indications include different types of cheese: Sombor cheese, Homolje sheep's cheese, Homolje goat's cheese, Homolje cow's cheese, Svrljig kashkaval, Balkan Mountains kashkaval, Pirot cow's kashkaval, Zlatar cheese, Sjenica sheep's cheese, Sjenica cow's cheese. Regardless of raw material (cow's, goat's, sheep's milk etc.), cheese production is characteristic of the regions it comes from. When it comes to cheese, the origin name represents the connection between historical and geographical dimensions. The climate influence and soil type, location, natural vegetation, types of cultivated plants, the way of keeping animals and animal breeds impact the originality and uniqueness of the finished product - cheese. Cheese protectted by Traditional Specialty Guaranteed TSG means that this cheese has specific characteristics because of the production method or traditional structure and is independent of a specific area (Milanović, 2006).

In accordance with the provisions of the Republic of Serbia, Užice (beef) ham, Užice bacon, Srem kulen, Srem domestic sausage, Srem salami, Požarevac sausage, Petrovska klobasa - Bački Petrovac (Ikonić et al., 2014), Lemeš kulen (Vuković et al., 2012) and Vršac ham also have geographical indications. The potential for sheep farming can be seen in the protected geographical indications of traditional specialties such as "Homolje's lamb", "Sjenica's lamb", but "Svrljig's" and "Krivi Vir's sheep", "Balkan's goat" and "Pirot's lamb" can be recognized as well.

In the Republic of Serbia a traditional method of sheep farming was preserved, with herds grazing on mountain slopes. Nutrition is based on feeding on natural hay exclusively throughout the year, with additional nutrition without concentrates (Kopanja, 2016).

It is known that the specificity of traditional production originating from Vojvodina is a rich legacy, which has been passed from generation to generation for many years. The production of Sombor cheese began on family farms of the Bačka District where sheep were raised. It is named "Sombor" after the town of Sombor where it was usually sold. It is prized and popular thanks to the original production method, shaping and maturation. Sombor cheese of soft consistency, a fine specific flavour and aroma, nowadays is usually made from sheep's, cow's or mixed milk. It is similar to the softer type of Trappist.

The Srem District is geographically very specifically defined by the flows of three 
rivers- the Sava, the Danube and the Bosut, and it is divided into a highland "wine" area, because the first grapevine dates back to $3^{\text {rd }}$ century $A D$ and was planted by a Roman emperor Probus who was born in the Srem District; and a lowland "pig" area for once famous pig breed - the Mangalica, that is today unfortunately bred only in reserves. Because of the unique geographical position compared to other regions of this country and its specific climate conditions for the production of many agricultural and food products, this region has for centuries been a great producer of high-quality pork meat and its specific processing has a very long tradition. Srem kulen (a flavoured sausage) and Srem sausage are fermented cured meat products that until the mid-fifties of the last century were produced exclusively on agricultural farms (Vesković-Moračanin et al., 2011).

According to the available data, the production of Srem sausage and kulen began in the middle of the $18^{\text {th }}$ century. There are assumptions that the forerunner of today's Srem sausage was spicy and smoked "Lucanica" that Roman soldiers carried in their backpacks for battle encouragement before, and invigorating refreshment after fierce battles. According to historical data, before $20^{\text {th }}$ century, in the territory of Srem and Sremska Mitrovica, former Sirmium, "Lucanica" was produced, whose recipe was brought by soldiers from southern Italian province Lucania in the period around the $1^{\text {st }}$ century AD. It was accepted by people as a spicy and smoked sausage, and the recipe was noted down by the then well-known chef Marcus Gavius Apicius $(80-40 \mathrm{BC})$. The recipe still can be found in the Vatican Library in Rome as a credible document. Lucanica is a product that besides qualitative properties also has a regional and historical aspect. It is a sophisticated technological product which has survived for 20 centuries and left a permanent mark woven into the culture of the cuisine of Srem.

In the past, when only one kulen was made from one pig, its consumption was related to specific important special and family events (harvest, wedding, birth, baptism...).
With the development of meat industry, the production of industrial type of Srem kulen and sausage began. Today, kulen is bought for important guests or as a gift on special occasions. Kulen is a smoked meat specialty made from selected pork meat and it brings utter gourmet delight. The production process lasts from 6 to 9 months and it consists of a series of specific technological procedures connected with pig farming and meat processing technology. In the production of homemade kulen, only the high-quality pork meat and natural additives are used. Characteristics of the finished product are high nutritive value, specific organoleptic properties, exceptionally beautiful colour, aroma and ripe meat taste (Vuković et al., 2011).

Unlike inheriting the traditional production methods, the mountainous part of the Republic of Serbia is also characterized by a specific product composition resulting from grazing animals throughout the year.

The geographical origin of Homolje sheep's, goat's and cow's cheese in brine is related to the Homolje mountains located in the Braničevo District. The name of the district dates back to the Middle Ages and it was often the subject of conflict between Byzantium, Hungary and Bulgaria, and later between Serbia and Hungary. Thanks to its location, it had an immense economic significance, and the people of Dubrovnik (1 $15^{\text {th }}$ century) spoke of a "very rich" region. The Braničevo District is very interesting for its geographical position with highland and lowland, but also for different climates (a harsh highland climate and a lowland humid continental climate), that also represent the characteristic of the district.

Kashkaval (cheese made of steamed dough) is the most famous cheese from the group that includes many in a way similar, but also different types of cheese in the Republic of Serbia (Milanović Z. 2006). The natural border with Bulgaria, $150 \mathrm{~km}$ long, was included in the category of natural resources of the Republic of Serbia, suitable for animal farming, sheep in particular. Pirot kashkaval made from sheep's milk was primarily intended for 
export. The production presented as a craft required special training and practice and this is why the cheese was produced in commercial companies for a known buyer, usually from abroad. Pirot kashkaval was recognizable in the last century and it was among the first types of cheese made from steamed dough originating from Serbia. It could be found on the tables of the White House, Damascus, Baghdad; it was sold in Greece and around the EU. Cheddar cheese originating from England is considered very similar to the domestic Pirot kashkaval. As the skill of cheese production was passed quickly, other brands appeared as well: Dimitrovgrad, Bela Palanka, Svrljig, Sokobanja, and then Banat cheese (Milanović, 2006). Nowadays, for the lack of human factor and raw material (sheep's milk), the cheese is made from cow's milk, as it was protected.

White cheeses in brine are typical of Serbia. They are made from fresh sheep's, cow's, goat's or mixed milk. As a rule, their slices are square-shaped. Svrljig or Balkan Mountains cheese, Krivi Vir or Homolje cheese are significant varieties of eastern mountain-type of white cheeses (Milanović, Z. 2006).

For the preparation of Pirot ironed sausage, carefully selected goat's meat, mutton and beef, the so-called "lean" type of meat, are used, and in the opinion of many consumers donkey meat is the best ("Pirotska peglana kobasica", n.d.). This type of sausage is an excellent specialty and it has not yet been protected by geographical indications. It is assumed that it dates back to the period of the Ottoman rule. All blood vessels, fat, tallow are extracted from the meat (only the best quality meat is used). It is minced and mixed with spices. After being filled, the sausage is tied in the shape of a horseshoe and then dried. The Pirot climate is suitable for it, the optimum temperature should be between zero and five degrees centigrade, without humidity and hard frost. This is why the best period for making the ironed sausage is the end of November or the end of December. During the period of drying, the sausages are "ironed" several times (usually by a bot- tle), which is why they are called "ironed", and after this, they take the form of a horseshoe. In this way, water is drained and durability is ensured.

The Pešter plateau, which is the largest plateau in the Balkans and one of the largest on the European continent, with an altitude of 1150 meters and area of 63 square kilometers is a vast expanse of gently rolling pastures with the herds of sheep, cattle and horses. This plateau has natural potentials with extraordinary agroecological values and has always been destined for animal farming and traditional agricultural production. Zlatar cheese, Sjenica sheep's and cow's cheese belong to the group of western mountaintypes of white Serbian cheeses (Milanović Z. 2006).

Sheep's cheeses have traditionally been produced in Serbia, and today are usually substituted for cow's cheeses. As goats are usually raised in the same areas and farms as sheep, their milk was mixed during the production of traditional mixed cheese in Serbia. Nowadays, the production of goat's cheese is more widespread and the Republic of Serbia is becoming recognizable by it even outside its borders. Goat's cheese is made in the same way as sheep's or cow's cheese. The characteristic of milk lipid droplets is that they are smaller and casein curds are slightly softer compared to cow's or sheep's cheese. Today, white goat's cheese or hard goat's cheese are the most common.

In the domestic cheese production industry recognizable brands of the following producers can be found on the market: Delikates Kuč kashkaval 35\%; Baker's Kuč kashkaval; semi-hard, semi-fat, soft and fresh goat's semi-hard cheese - mature white sliced cheese; soft full-fat goat's cheese wrapped in chestnut leaves, cottage cheese, young cheese...

Significant milk products from Serbia are also kajmak (a creamy dairy product), processed cheese...It can be said that kajmak is the name of Serbian origin.

However, the same product (pronounced the same with different accent) exists in Iraq (former Mesopotamia), which can be 
an indicator of the ancient Serbian culture migration. Besides in Serbia, kajmak is also produced in Herzegovina and Monte- negro, but young kajmak that is mainly produced in Serbia could have a protected name (from Kraljevo, Čačak, Užice...).

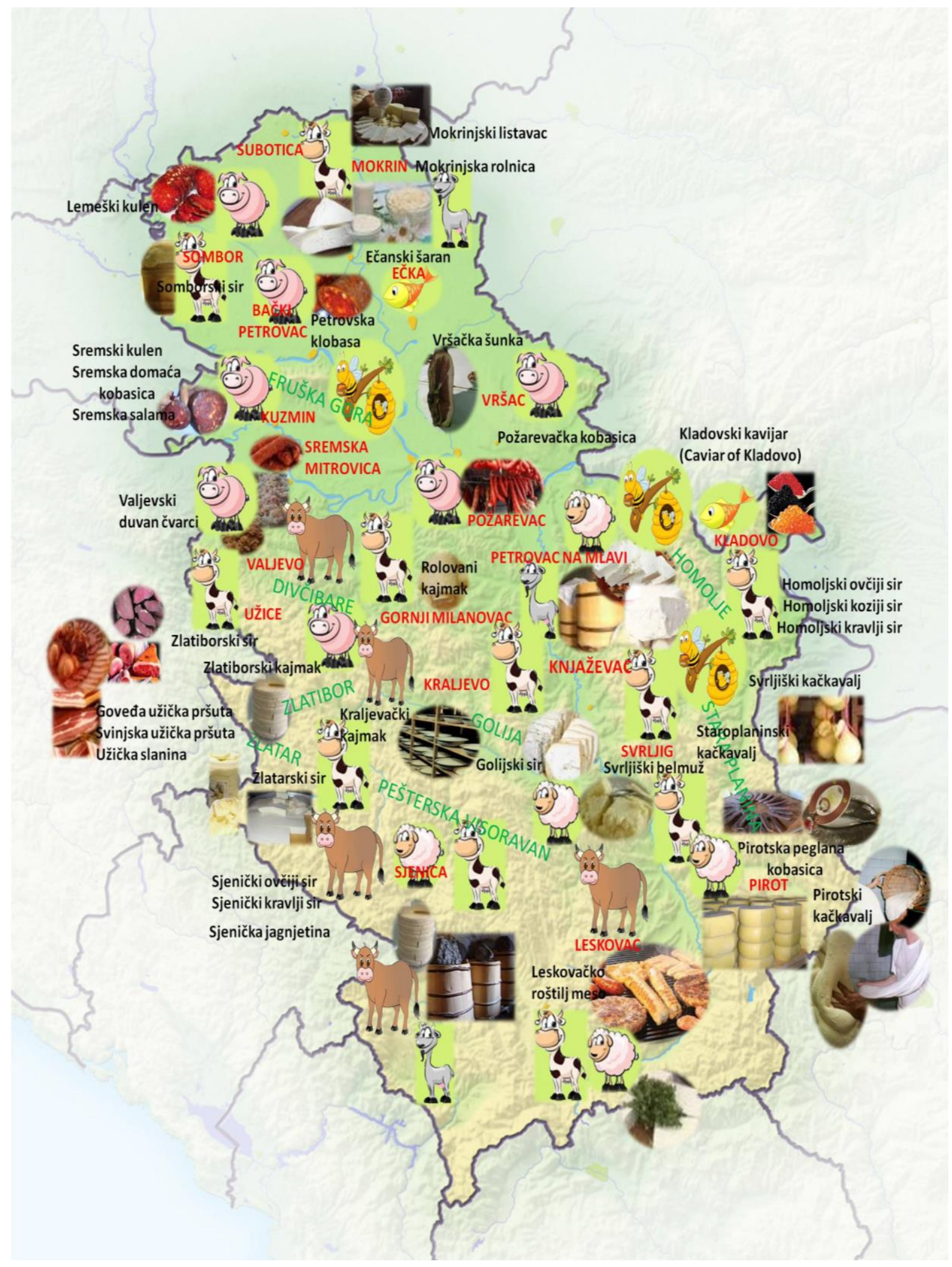

Figure 1. Traditional products of animal origin from regions of the Republic of Serbia 
The protection and encouragement of the production of autochthonous cheese and traditional meat products are the result of new EU agricultural policy. This policy on the one hand aims to expand trade exchange, reduce the reserves of industrial milk and meat products and protect the products from disappearance and imitation.

On the other hand, it is directed at helping the consumer to recognize the specific character of the product of animal origin. At the same time, it aims to stimulate a certain form of extensive agricultural production which contributes to environmental protection, the preservation of rural areas and biodiversity.

In addition to physical factor, tradition and experience that are passed from generation to generation are of utter importance in the verification of the cheese origin name. The encouragement of the wider use of production process to obtain meat product with geographical origin has economic, cultural and social aspect. The production of meat products in a traditional way with the secured product positioning in domestic and foreign markets through large retail chains will contribute to a better economic position of farmers. Broadly speaking, it seems to encourage further animal farming development, sustainable economic development of the region and the decrease in unemployment and poverty rate.

The Law on Food Safety (Zakon o bezbednosti hrane, 2009) and other relevant regulations pay special attention to the consumer's health protection (Zakon o zaštiti potrošača, 2002). With these structural societal changes, every consumer is bound to "reward" a recognizable product with his purchasing habits and in this way to start fair trade in order to highlight the role and responsibilities of society.

\section{CONCLUSIONS}

It is of great significance to respect nature and the values given by the geographical diversity of the Republic of Serbia, with the planned use of the existent high percen- tage of unused arable land, without the excessive attempt to defeat and manipulate it. The most significant advantage of the "protected" product is facing the problem of unemployment and migration from rural areas, where one of the strategies for rural development is the preservation of heritage and encouragement of traditional activities of local population. Regarding this, it is necessary to work harder to emphasize the advantages of the protected geographical indications of a product, i.e. the certification of organic production.

A common feature of traditionnally protected products of animal origin and the sustainability of agricultural production are in the service of the base for future generations. The safe positioning of traditional, geographically protected products of animal origin provides the guarantee for jobs and promotes economy development in the rural regions.

\section{ACKNOWLEDGEMENTS}

This work is a part of Integrated and Interdisciplinary Research Project No. III 46012, funded by the Ministry of Education, Science and Technological Development of the Republic of Serbia.

\section{REFERENCES}

1. Ikonić, P., Tasić, T., Petrović, Lj., Ikonić, B., Tomović V., Džinić N., Škaljac S., Jokanović M., Šojić, B. (2014). Drying characteristics of traditional fermented sausage Petrovská klobása the effect of different ripening conditions and use of starter culture. Food and Feed Research, 41 (1), 71-79.

2. Kopanja, M. (2016). Pokazatelji ruralnog razvoja Republike Srbije, PhD Thesis, Fakultet za ekonomiju i inženjerski menadžment, Novi Sad, Serbia.

3. Milanović, Z. (2006). Srpski sir i kajmak u evropskom okruženju, Institut za ekonomiku poljoprivrede, Beograd, p.176.

4. Pirotska peglana kobasica (n.d.). Retrieved from www.peglana.com.

5. Ministarstvo poljoprivrede, šumarstva i vodoprivrede RS (2009). Edukacija proizvođača o značaju proizvodnje proizvoda sa geografskim poreklom. In Geografska zaštita tradicionalnih srpskih proizvoda, dobar put do evropskog tržišta. Ministry of Agriculture, Forestry and Wa- 
ter Management of the Republic of Serbia, Belgrade.

6. Pravilnik o deklarisanju, označavanju i reklamiranju hrane (2013). Službeni glasnik RS, 85/13.

7. Pravilnik o kvalitetu usitnjenog mesa, poluproizvoda od mesa i proizvoda od mesa (2012). Službeni glasnik RS, 31/12.

8. Pravilnik o metodama organske stočarske proizvodnje (2002). Službeni list SRJ, 51/2002.

9. Stevanović, J., Mirilović, M., Okanović, Đ., Karabasil, N., Pupavac, S. (2016). Traditional and recognizable products of animal origin from Serbia. $23^{\text {rd }}$ International Conference „KRMIVA 2016“, Opatija, Croatia, Book of Abstracts, p. 92

10. UNESCO (n.d.) Human rigts. International Education Server for Democracy, Peace and Human Rights Education (www.dadalos.org).

11. Vesković-Moračanin, S., Karan, D., Okanović,
Đ., Jokanović, M., Džinić, N., Parunović, N., Trbović, D. (2011). Colour and texture properties of traditionally fermented 'Sremska' sausage. Tehnologija mesa, 52, 245-251.

12. Vuković, I., Saičić, S., Vasilev, D. (2011) Contribution to knowledge of major quality parameters of traditional (domestic) kulen. Tehnologija mesa, 52 (1), 134-140.

13. Vuković I., Vasilev, D., Saičić, S., Ivanković, S. (2012). Investigation of major changes during ripening of traditional fermented sausage Lemeški kulen. Tehnologija mesa, 53, 140-147.

14. Zakon o zaštiti potrošača (2002). Službeni list SRJ, 37/02.

15. Zakon o organskoj poljoprivredi (2000). Službeni list SRJ, 28/00.

16. Zakon o bezbednosti hrane (2009). Službeni glasnik RS, 41/09.

17. Zakon o oznakama geografskog porekla. Službeni glasnik RS, 18/2010.

\section{ТРАДИЦИОНАЛНИ ПРОИЗВОДИ - ОСНОВЕ ЗА ОДРЖИВИ РАЗВОЈ ПРОИЗВОДА ЖИВОТИњСКОГ ПОРЕКЛА У СРБИЈИ}

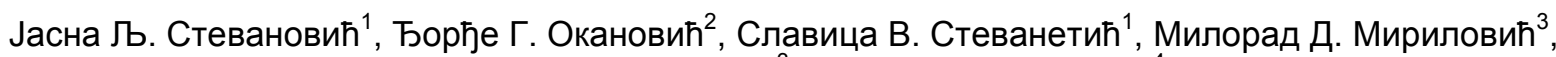
Неђељко Р. Карабасил ${ }^{3}$, Сњежана Р. Пупавац ${ }^{4}$

${ }^{1}$ Привредна комора Србије, Ресавска 15, 11000 Београд, Србија

${ }^{2}$ Универзитет у Новом Саду, Научни институт за прехрамбене технологије у Новом Саду, 21000 Нови Сад, Булевар цара Лазара 1, Србија

${ }^{3}$ Универзитет у Београду, Факултет ветеринарске медицине, Бул. ослобођења 18, 11000 Београд, Србија

${ }^{4}$ ЕКО ЛАБ доо Падинска Скела, Индустријско насеље бб, Србија

Сажетак: Резултати многобројних истраживања о разноврсности традиционалних производа животињског порекла са одређених подручја Републике Србије, пружају могућност да постану део одрживог развоја квалитета, који би био заснован на њиховој промоцији и заштити локалних ресурса. Традиционални производи животињског порекла, међусобно се разликују, неодвојиви су део локалног идентитета, типични за народ и њихову културу у припремању хране. Полазећи од чињенице да је Република Србија богата разноврсношћу ових производа, уочавамо њихове предности и специфичности, које доносе предност избора домаћем и страном потрошачу. Кроз стицање поверења, али и заштиту од заборава, вредност домаћих производа, сачувала је вековну традицију, препознатљив укус и поднебље Србије из којег долази.

Универзално прихваћени модели руралних институционалних структура не постоје, већ се прилагођавају и развијају према потребама, могућностима и специфичностима одређеног подручја. Ефикасном заштитом, постају подстицај за инвестирање и допринос укупном економском и привредном напретку друштва.

Кључне речи: традиционални производи животињског порекла, региони Србије, заштита порекла

Received: 3 November 2016

Accepted: 29 November 2016 